\title{
NON-LINEAR AND LAGGING CONVERGENCE EFFECTS OF THE EU'S REGIONAL SUPPORT AT NUTS 3 LEVEL
}

\author{
Mindaugas BUTKUS, Diana CIBULSKIENĖ, Alma MAČIULYTĖ-ŠNIUKIENĖ, \\ Kristina MATUZEVIČIUTÉ \\ Šiauliai University, Šiauliai, Lithuania
}

\begin{abstract}
Reduction of the territorial disparities in terms of their development level is the main aim of the European Union's (EU's) regional support. Most of the previous studies investigate the linear relationship between support and growth at countries' or NUTS1/2 disaggregation level, omitting the question on what is the impact of this support on regional convergence among NUTS3 regions and on whether non-linear effects occur. To fill this gap, we modified the difference-in-differences estimator to test empirically the non-linear convergence effects of the EU's regional support at NUTS 3 level over the 2000-2006 programming period, taking into account the possible lagging effect. The results revealed that the impact of regional support on convergence is positive with the diminishing marginal effect as the intensity of payments is increasing. Moreover, we find evidence that the return is higher for the post-intervention compared with the intervention period, i.e. the convergence outcomes of the EU's support occur in the long-run.
\end{abstract}

Key Words: regional disparities, convergence, NUTS 3, non-linear effects.

\section{Introduction}

The EU's regional support aims to ensure the growth of the least developed regions in order to reduce territorial disparities. To achieve this goal, the European Commission (EC) uses support from the Cohesion (CF) and Structural (SF) funds. Approximately 160 billion euro were allocated from these funds to the EU's Member States (MS) over the 2000-2006 programming period. The question of interest is whether this support has achieved its objectives, if it has boosted growth in the least developed regions and if it led to regional convergence. The analysis of previous research, however, disclosed that most of the papers investigate the impact of SF and CF on regional growth (GDP per capita and employment) at country, or NUTS1/2 disaggregation level, leaving open the question on what impact SF and CF have on convergence, especially at NUTS3 level.

The leading article by Becker et al. (2018), covering the four last programming periods, revealed the positive effect of the SF on economic growth in NUTS2 regions and it noted that this effect does not last long. Moreover, Becker et al. (2013) found that SF payments positively influence only about $30 \%$ of the EU-25 NUTS2 regions by revealing the heterogeneity of the effect. Kyriacou and Roca-Sagalés (2012) assessed the effects of SF transfers on the convergence among $14 \mathrm{EU}$ countries and it also concluded that the effect of SF treatment is heterogeneous. Although studies (Rodríguez-Pose and Novak 2013, Pinho et al. 2015, Becker at al. 2018, Piętak 2018) show that EU's regional support has become more efficient over the last two programming periods, compared to the previous ones, the efficiency problem of SF and CF allocations persists as CP underestimates the importance of transfer intensity which might influence the return on support.

Just a few studies estimate the non-linear relation between the EU's regional support and economic growth or/and convergence ascertaining the potentially decreasing marginal effect when transfer intensity is increasing. Wostner and Šlander (2009), Kyriacou and Roca-Sagalés (2012), Becker et al. (2012), Pinho et al. (2015), Pontarollo (2016), Cerqua and Pellegrini 
(2018), Di Cataldo and Monastiriotis (2020) investigated how the return on SF depends on the intensity of the transfers. They all have revealed that SF intensity should not exceed the maximum desirable levels in order to avoid the inefficiency of CP. Hagen and Mohl (2008) made a contrary conclusion that it does not matter which "dose" of SF transfers the regions have received because the impact of SF transfers on regional growth rates is not significant. However, the study could have revealed no significant impact since the long-term effects were not assessed. SF and CF can have both short-run and long-run effects. According to Cappelen et al. (2003: 16), "while the former occurs more or less instantaneously, the latter may take several years to materialise". Thus, it is crucial to evaluate the impact of SF and CF over both, i.e. financial intervention and post-intervention, periods.

All studies dealing with non-linear or lagged effects of SF treatment intensity estimated the impact on economic growth (except Kyriacou and Roca-Sagalés 2012), leaving open the question of what is the effect on convergence. Kyriacou and Roca-Sagalés (2012) investigated the non-linear SF effects on convergence, but their study (likewise Beugelsdijk and Eijffinger 2005, Wostner and Šlander 2009) covered the countries' disaggregation level. The research of Rodríguez-Pose and Fratesi (2002), Hagen and Mohl (2008), Mohl and Hagen (2008, 2010), Pinho et al. (2015), Bondonio and Pellegrini (2016), Pontarollo (2016), Cerqua and Pellegrini (2018), Di Cataldo and Monastiriotis (2020) covered NUTS1/2 regions. Just Becker et al.'s $(2010,2012)$ studies were conducted at NUTS3 level, but they do not evaluate the non-linear effects of SF on convergence. Hence, it is unclear whether SF and CF have non-linear effects on convergence, especially at NUTS3 level.

To fill these gaps, our paper aims to (i) develop a model suitable to examine the impact of EU's regional financial support on disparities; (ii) assess what effect the EU's regional financial support had on regional convergence one being the primary goal of the CP. We focus on rarely analysed NUTS3 disaggregation level and we take into account the possible diminishing marginal and lagging effects of EU's regional financial support.

The rest of the paper is structured as follows: the second section presents the review of contributions on non-linear and lagging effects of EU's regional support on growth and convergence, the third section describes the methodology and estimation strategy, the fourth section presents the estimation results, the next section presents the discussion, and the last section concludes the paper.

\section{Literature review}

There are a few studies that tested other than a linear functional form of the relationship between the intensity of SF and CF payments and the outcome variable (Table 1).

The analysis of previous studies, which estimate the non-linear relationship between SF and CF transfers and economic growth or convergence, has revealed, that, after a certain intensity threshold, additional payments are not associated with higher returns. However, too low intensity of SF and CF payments does not allow to achieve significant positive outcomes. According to Becker et al.'s (2012) findings, an optimal desirable level of transfer's intensity is $0.4 \%$ of regional GDP, and when the intensity of the transfers reaches $1.3 \%$ of GDP, additional payments do not generate positive returns. Pontarollo's (2016) findings supplemented the results of Becker et al.'s (2012) study. He concludes that the intensity of SF payments should not exceed $0.15-0.70 \%$ of the GDP and a particular desirable intensity level depends on the SF allocation (intervention) area. If SF expenditures on infrastructure development exceed $0.70 \%$ of the GDP, the marginal effect of SF transfers becomes negative. The intensity of SF payments for a productive environment should be even lower - not to exceed $0.15 \%$ of the GDP. Wostner and Šlander (2009), and Kyriacou and Roca-Sagalés (2012) investigate the non -linear relationship between the intensity of SF treatment, the amount of structural expenditure 
Non - Linear and Lagging Convergence Effects of the EU'S Regional Support Nuts 3 Level

Table 1

Estimation results of previous studies on the non-linear effects of SF transfers

\begin{tabular}{|c|c|c|c|c|c|c|c|}
\hline $\begin{array}{c}\text { Research } \\
\text { by }\end{array}$ & $\begin{array}{l}\text { Covered } \\
\text { period }\end{array}$ & $\begin{array}{c}\text { Disaggre- } \\
\text { gation } \\
\text { level }\end{array}$ & $\begin{array}{l}\text { Applied } \\
\text { method* }^{*}\end{array}$ & $\begin{array}{l}\text { Outcome } \\
\text { variable }\end{array}$ & $\begin{array}{l}\text { Overall im- } \\
\text { pact }\end{array}$ & $\begin{array}{c}\text { Does SF } \\
\text { transfer } \\
\text { intensity } \\
\text { matter? }\end{array}$ & $\begin{array}{c}\text { Desirable } \\
\text { level }\end{array}$ \\
\hline $\begin{array}{l}\text { Wostner } \\
\text { and } \\
\text { Šlander } \\
(2009)\end{array}$ & $\begin{array}{l}\text { 1990-1993, } \\
1994-1999 \\
2000-2006\end{array}$ & $\begin{array}{l}\text { EU-15, } \\
\text { Country- } \\
\text { level }\end{array}$ & FE & STREXP $P^{* *}$ & $\begin{array}{l}\text { Positive, } \\
\text { significant }\end{array}$ & Yes & $\begin{array}{l}\text { Max } \\
\sim 2.33 \% \text { of } \\
\text { countries } \\
\text { GDP, Opti- } \\
\text { mal } \\
\text { ND } \\
\sim 1.75 \% \text { of } \\
\text { countries } \\
\text { GDP }\end{array}$ \\
\hline $\begin{array}{l}\text { Becker et } \\
\text { al. }(2012)\end{array}$ & $\begin{array}{l}\text { 1994-1999, } \\
2000-2006\end{array}$ & $\begin{array}{l}\text { EU } \\
\text { NUTS3 } \\
\text { regions }\end{array}$ & MGPS & $\begin{array}{l}\text { Economic } \\
\text { growth }\end{array}$ & $\begin{array}{l}\text { Positive, } \\
\text { significant }\end{array}$ & Yes & $\begin{array}{l}\text { Max } \sim 1.3 \% \\
\text { of regional } \\
\text { GDP; Opti- } \\
\text { mal } \sim 0.4 \% \\
\text { of regional } \\
\text { GDP, Min } \\
- \text { ND }\end{array}$ \\
\hline $\begin{array}{l}\text { Kyriacou } \\
\text { and Roca- } \\
\text { Sagalés } \\
(2012)\end{array}$ & $\begin{array}{l}1994-1999 \\
2000-2006\end{array}$ & $\begin{array}{l}\text { EU-14, } \\
\text { Country- } \\
\text { level }\end{array}$ & $\begin{array}{l}\text { Feasible } \\
\text { GLS, } \\
\text { SUR }\end{array}$ & $\begin{array}{l}\text { Conver- } \\
\text { gence }\end{array}$ & $\begin{array}{l}\text { Positive, } \\
\text { significant }\end{array}$ & Yes & $\begin{array}{l}\text { Max -ND, } \\
\text { Optimal - } \\
\text { ND, Min } \\
\sim 1.6 \% \text { of } \\
\text { countries } \\
\text { GDP }\end{array}$ \\
\hline $\begin{array}{l}\text { Pinho et } \\
\text { al. }(2015)\end{array}$ & $\begin{array}{l}1995-1999 \\
2000-2006 \\
2007-2009\end{array}$ & $\begin{array}{l}\text { EU-12, } \\
\text { NUTS 1/2 } \\
\text { regions }\end{array}$ & FE & $\begin{array}{l}\text { Economic } \\
\text { growth }\end{array}$ & $\begin{array}{l}\text { Positive, } \\
\text { significant }\end{array}$ & Yes & $\begin{array}{l}\text { Max 3\%, } \\
\text { Optimal - } \\
\text { ND, Min } \\
\sim 1,9 \% \text { of } \\
\text { countries } \\
\text { GDP }\end{array}$ \\
\hline $\begin{array}{l}\text { Bondonio } \\
\text { and Pelle- } \\
\text { grini } \\
(2016)\end{array}$ & $\begin{array}{l}1994-1999 \\
2000-2006 \\
2007-2013\end{array}$ & $\begin{array}{l}\text { EU-15, } \\
\text { NUTS-2 } \\
\text { level }\end{array}$ & $\begin{array}{l}\text { PSM, } \\
\text { GPS, } \\
\text { RDD }\end{array}$ & $\begin{array}{l}\text { Economic } \\
\text { growth }\end{array}$ & $\begin{array}{l}\text { Positive, } \\
\text { significant }\end{array}$ & Yes & ND \\
\hline $\begin{array}{l}\text { Pontarollo } \\
(2016)\end{array}$ & $2000-2006$ & $\begin{array}{l}\text { EU-15, } \\
202 \text { NUTS } \\
1 / 2 \text { re- } \\
\text { gions }\end{array}$ & $\begin{array}{l}\text { GAM, } \\
\text { GLMs }\end{array}$ & $\begin{array}{l}\text { Economic } \\
\text { growth }\end{array}$ & $\begin{array}{l}\text { Positive or } \\
\text { negative } \\
\text { depending } \\
\text { on the inter- } \\
\text { vention ar- } \\
\text { ea, signifi- } \\
\text { cant }\end{array}$ & Yes & $\begin{array}{l}\text { Max }-0,15 \\
-0,70 \% \text { of } \\
\text { regional } \\
\text { GDP de- } \\
\text { pending on } \\
\text { the inter- } \\
\text { vention } \\
\text { area. Opti- } \\
\text { mal - ND, } \\
\text { Min - ND. }\end{array}$ \\
\hline $\begin{array}{l}\text { Cerqua } \\
\text { and Pelle- } \\
\text { grini } \\
(2018)\end{array}$ & $\begin{array}{l}1994-1999 \\
2000-2006\end{array}$ & $\begin{array}{l}\text { EU-15, } \\
208 \text { NUTS } \\
2 \text { regions }\end{array}$ & RDD & $\begin{array}{l}\text { Economic } \\
\text { growth }\end{array}$ & $\begin{array}{l}\text { Positive on } \\
\text { GDP per } \\
\text { capita } \\
\text { growth, in- } \\
\text { significant } \\
\text { on GVA }\end{array}$ & Yes & $\begin{array}{l}\text { Max - 305- } \\
340 € \text { per } \\
\text { capita, } \\
\text { Optimal - } \\
\text { ND, Min - } \\
\text { ND }\end{array}$ \\
\hline $\begin{array}{l}\text { Di Cataldo } \\
\text { and Mo- } \\
\text { nastiriotis } \\
(2020)\end{array}$ & $1994-2013$ & $\begin{array}{l}\text { UK, } 37 \\
\text { NUTS } 2 \\
\text { regions }\end{array}$ & $\begin{array}{l}\text { SLDV } \\
\text { (FE), } \\
\text { SPL'(FE) }\end{array}$ & $\begin{array}{l}\text { Economic } \\
\text { growth }\end{array}$ & $\begin{array}{l}\text { Positive, } \\
\text { significant }\end{array}$ & Yes & ND \\
\hline
\end{tabular}

* MGPS - Method of Generalized Propensity Score, GLS - General Least Squares, SUR - Seemingly Unrelated Regression, FE - Fixed Effects Model, PSM - Propensity Score Matching, GPS - Generalised Propensity Score, RDD - Regression Discontinuity Designs, GAM - General Additive Model, GLMs Semi-parametric Generalised Linear Model, LSDV - Least Squares Dummy Variables, SPL - Spatial Panel Lag.

** STREXP - Amount of structural expenditure, i.e. the sum of all public spending at all levels of government, for economic purpose.

${ }_{* * *}^{*} \mathrm{ND}$ - No data presented. 
and the convergence at the country level. The studies revealed the significant positive impact of SF transfers when their intensity reached approximately $1.6-1.75 \%$ of the countries' GDP. According to Wostner and Šlander (2009), when the SF transfers exceed $2.33 \%$ of the countries' GDP, they do not promote structural expenditures. According to Pinho et al.'s (2015) findings, this boundary lies at 3\% of the countries' GDP, according to Cerqua and Pellegrini (2018) - at 305-340 € per capita. Bondonio and Pellegrini (2016), as well as Di Cataldo and Monastiriotis (2020), agree that the intensity of SF and CF transfer affects the returns, but do not provide a desirable level.

Beugelsdijk and Eijffinger (2005) provided a justification of the non-linear form of relationship using the moral hazard phenomenon and the substitution effects. We can argue that the regions, by using the SF support efficiently and inducing a faster growth of the desirable outcome(s), would later become ineligible for financial support. Regions receive structural financial support only below a certain level of development. If the level of regional development is at a critical eligibility level, which could reduce the EU financial support in the future, the regions may tend to manipulate the statistics. In other words, due to the moral hazard phenomenon, SF payments are used for an inappropriate project in a way to continue being financially supported. The difficulty of testing the effect of moral hazard is related to its measurement problem. Especially it can happen at the regional level because it is hard to disentangle from the other (unforeseen) types of inefficient use of funds. Beugelsdijk and Eijffinger (2005) included a corruption index in their model, but the results do not indicate that the countries with a higher corruption level use the regional support more inefficiently.

Another effect that might arise is the substitution effect. The distribution of EU funds is bound with the principle of additionality, which ensures that national and/or local resources accompany the EU's regional support (Wallace et al. 2015). The substitution effect is the result of inefficient public support schemes when beneficiary regions reduce their resources and amend them with the EU's regional support. The research (Beugelsdijk and Eijffinger 2005, Marzinotto 2012, Del Bo et al. 2011, Szitásiová et al. 2014) revealed that different substitution effects occur. In the long-run, the impact of the substitution of local resources with the EU's regional support is perceived as a lack of absorptive capacity of the local authorities. The reason is that once the public entities replace their resources with the EU's regional support, they would eventually have to invest even more in the case of a loss of external funding. Another reason is that, while replacing the local resources, EU's regional support loses its importance and, therefore, the investments become unnecessary without multiplicative impacts in the lagging regions. Barca (2009) emphasised that regional policies aim to encourage amendments in the behaviour of private actors in the regions where either inefficiency or a social exclusion trap exists, but not to compensate the inability of the local authorities to generate sufficient revenue from their sources to finance the regional development. Regional support in some cases even creates a culture of dependency. The other problem related to the substitution effect, which is highlighted by Ederveen et al. (2003), as well as Beugelsdijk and Eijffinger (2005), is that regional support may offset the impact of private investment if it finances the projects that are close substitutes for the private capital.

Becker et al. (2012) argued that the additional financial support has no effect on the outcome when the intensity of the support reaches the threshold level since SF transfers are mainly directed to investment projects and since investments are subject to diminishing marginal returns. The assumption of diminishing returns is naturally derived from the neoclassical theory of production. This assumption implies that the more investment projects are carried out, the lower return is expected from additional investments (or transfers) (European Commission 2016).

In the previous contributions, we can find arguments that some regions are using EU funding inefficiently if the intensity of transfers is increasing. If EU regional transfers are subject to 
diminishing returns, it is not sufficient to estimate that transfers on average have a positive effect on growth (Becker et al. 2012). It is also essential to estimate how the different levels of transfers' intensity are related to regional growth. This would allow seeing up to which level the transfers are fostering regional growth and beyond which level the further transfers become inefficient. If diminishing the marginal returns of transfers empirically manifest, we can identify a maximum desirable level of a transfers' intensity. In this case, beyond a determined maximum of desirable level of SF transfers' intensity, no additional (or even lower) growth effects would be generated. Becker et al. 2012, Pinho et al. 2015, Pontarollo 2016, Cerqua and Pellegrini 2018 argued that SF in the richer MS is now producing diminishing marginal returns with no visible value-added over what might be achieved by the national programmes. Gorzelak (2016) assumed that the effects of the diminishing marginal returns could appear as the different effects of the particular types of intervention in the different types of territories. Hence, the diminishing marginal returns of SF transfer intensity can differ among European regions depending on the development level, accumulated social capital, and potential demand (European Commission 2016).

Since incentives for misallocation, substitution effects, and diminishing marginal returns are all likely to correlate with a higher intensity of financial support, we can expect to observe an inverted U-shaped quadratic form of a relationship between the intensity of support and the outcome. It would indicate that with a higher level of regional financial support intensity, additional support may positively affect the desired outcome, but beyond some level of intensity, the marginal positive effects on the outcome might disappear or even become reverse.

Another limitation of previous studies on evaluating SF and CF returns is that in most cases research considers only short-term effects. However, CP treatment may have an effect over the long-run as well. There could be cases when the positive effect of regional support can occur over the current year of the investment and it can last for a couple of years, and cases when the positive effect can start to manifest a few years after the investment, depending on the SF and CF intervention area. For example, the positive effects of an investment in infrastructure may take several years to materialise. Just a few previous studies estimated the possible lagged effects of SF and CF (Table 2). It should be noted that all of them assessed the impact of SF and/or CF on economic growth (GDP per capita, employment), omitting the question of what is the lagged effect on convergence.

The analysis of previous studies on lagged or continuing SF and CF treatment effects has disclosed that, first, the overall positive effect of SF on economic growth may last three years ahead (Beugelsdijk and Eijffinger 2005), evaluating the impact at a country level. However, it is not clear how long the positive effect lasts at a regional level, especially in the case of convergence. Second, a significant effect of SF may be delayed, i.e. it occurs after a specific time lagging from 1 up to 6 years, depending on the intervention area (Rodríguez-Pose and Fratesi 2002, CSIL and DKM Economic Consultants 2012) or support Objectives (Becker et al. 2010, Mohl and Hagen 2008, 2010). This makes it reasonable to assert that the evaluation of SF and CF return has to cover estimations for both short-run and long-run effects.

\section{Methodology}

Aiming to examine the potentially non-linear relation between the regional support intensity and the desired outcome of the CP to diminish the disparities among EU regions, we ground our model on a difference-in-differences (DID) approach. The initial specification of the linear regression equation, which allows estimating the homogeneous DID parameter, is:

$$
y_{i}=\delta_{0}+\delta_{1}-t 2+\delta_{2}-s_{i}+\delta_{D I D}-t 2 \cdot s_{i}+\varepsilon_{i}
$$


Mindaugas BUTKUS, Diana CIBULSKIENĖ, Alma MAČIULYTÉ-ŠNIUKIENĖ, Kristina MATUZEVIČIUTĖ

Estimation results of previous studies on delayed and continuous SF impact

\begin{tabular}{|c|c|c|c|c|c|c|c|}
\hline $\begin{array}{c}\text { Research } \\
\text { by }\end{array}$ & $\begin{array}{l}\mathrm{Pe}- \\
\text { riod }\end{array}$ & $\begin{array}{c}\text { Disaggre } \\
\text { - gation } \\
\text { level }\end{array}$ & $\begin{array}{l}\text { Applied } \\
\text { method }\end{array}$ & $\begin{array}{l}\text { Out- } \\
\text { come } \\
\text { varia- } \\
\text { ble }\end{array}$ & Overall impact & $\begin{array}{l}\text { Is the } \\
\text { lagged } \\
\text { effect } \\
\text { set? }\end{array}$ & Time lag \\
\hline $\begin{array}{l}\text { Rodríguez- } \\
\text { Pose and } \\
\text { Fratesi } \\
(2002)\end{array}$ & $\begin{array}{l}1989- \\
1999\end{array}$ & $\begin{array}{l}\text { EU NUTS } \\
2 \text { regions }\end{array}$ & $\begin{array}{l}\text { Pooled } \\
\text { GLS, } \\
\text { LSDV }\end{array}$ & $\begin{array}{l}\text { Eco- } \\
\text { nomic } \\
\text { growth }\end{array}$ & $\begin{array}{l}\text { Positive, signifi- } \\
\text { cant of total } \\
\text { payments. Posi- } \\
\text { tive, not signifi- } \\
\text { cant of Obj. } 1 \\
\text { payments }\end{array}$ & Yes & $\begin{array}{l}1-3 \\
\text { years } \\
\text { depend- } \\
\text { ing on the } \\
\text { interven- } \\
\text { tion area }\end{array}$ \\
\hline $\begin{array}{l}\text { Beugelsdijk } \\
\text { and } \\
\text { Eijffinger } \\
(2005)\end{array}$ & $\begin{array}{l}1995- \\
2001\end{array}$ & $\begin{array}{l}\text { EU-15, } \\
\text { Country- } \\
\text { level }\end{array}$ & $\begin{array}{l}\text { One and } \\
\text { two-step } \\
\text { GMM }\end{array}$ & $\begin{array}{l}\text { Eco- } \\
\text { nomic } \\
\text { growth }\end{array}$ & $\begin{array}{l}\text { Positive, signifi- } \\
\text { cant }\end{array}$ & No & $\begin{array}{l}\text { Three } \\
\text { years } \\
\text { ahead }\end{array}$ \\
\hline $\begin{array}{l}\text { Mohl and } \\
\text { Hagen } \\
\text { (2008) }\end{array}$ & $\begin{array}{l}1995- \\
2005\end{array}$ & $\begin{array}{l}\text { EU-15, } \\
124 \\
\text { NUTS } 1 / 2 \\
\text { regions }\end{array}$ & $\begin{array}{l}\text { LSDV, } \\
\text { GMM, } \\
\text { spatial } \\
\text { correla- } \\
\text { tion }\end{array}$ & $\begin{array}{l}\text { Eco- } \\
\text { nomic } \\
\text { growth }\end{array}$ & $\begin{array}{l}\text { Positive, signifi- } \\
\text { cant of Obj. } 1 \\
\text { payments. Neg- } \\
\text { ative, significant } \\
\text { of Objective } 2 \\
\text { and } 3 \text { payments }\end{array}$ & Yes & $\begin{array}{l}\sim 2-3 \\
\text { years }\end{array}$ \\
\hline $\begin{array}{l}\text { Becker et } \\
\text { al. }(2010)\end{array}$ & $\begin{array}{l}1989- \\
1993, \\
1994- \\
1999, \\
2000- \\
2006 \\
\end{array}$ & $\begin{array}{l}\text { EU-12, } \\
\text { EU-15, } \\
\text { EU-25 } \\
\text { NUTS 2/3 } \\
\text { regions }\end{array}$ & $\begin{array}{l}\text { RDD, } \\
\text { Pooled } \\
\text { OLS, FE }\end{array}$ & $\begin{array}{l}\text { Eco- } \\
\text { nomic } \\
\text { and } \\
\text { employ- } \\
\text { ment } \\
\text { growth }\end{array}$ & $\begin{array}{l}\text { Positive, signifi- } \\
\text { cant on growth, } \\
\text { insignificant on } \\
\text { employment }\end{array}$ & Yes & $\begin{array}{l}\sim 4-6 \\
\text { years } \\
\text { (Obj. 1) }\end{array}$ \\
\hline $\begin{array}{l}\text { Mohl and } \\
\text { Hagen } \\
\text { (2010) }\end{array}$ & $\begin{array}{l}1999- \\
2007\end{array}$ & $\begin{array}{l}\text { EU-15, } \\
130 \text { EU } \\
\text { NUTS 1/2 } \\
\text { regions }\end{array}$ & $\begin{array}{l}\text { GMM, } \\
\text { SDP }\end{array}$ & $\begin{array}{l}\text { Em- } \\
\text { ployme } \\
\text { nt } \\
\text { growth }\end{array}$ & $\begin{array}{l}\text { No significant of } \\
\text { total SF, vary } \\
\text { from positive to } \\
\text { negative, signifi- } \\
\text { cant Obj. } 1,2,3 \\
\text { payments }\end{array}$ & Yes & $\begin{array}{l}\sim 1-4 \\
\text { years } \\
\text { depend- } \\
\text { ing on } \\
\text { payment } \\
\text { type } \\
\text { (Obj.) }\end{array}$ \\
\hline $\begin{array}{l}\text { CSIL and } \\
\text { DKM Eco- } \\
\text { nomic Con- } \\
\text { sultants } \\
(2012)\end{array}$ & $\begin{array}{l}1994- \\
1999\end{array}$ & $\begin{array}{l}\text { EU-5 } \\
\text { (Greece, } \\
\text { Ireland, } \\
\text { Italy, } \\
\text { Portugal, } \\
\text { Spain), } \\
\text { Project } \\
\text { level }\end{array}$ & $\begin{array}{l}\text { Cost- } \\
\text { benefit } \\
\text { analysis }\end{array}$ & $\begin{array}{l}\text { Eco- } \\
\text { nomic } \\
\text { growth }\end{array}$ & $\begin{array}{l}\text { Positive, signifi- } \\
\text { cant }\end{array}$ & Yes & $\sim 5$ years \\
\hline
\end{tabular}

${ }^{*}$ GLS - General Least Squares, LSDV - Least Square Dummy Variable estimator, GMM - Generalized Method of Moments, RDD - Regression Discontinuity Designs, OLS - Ordinary Least Square, FE Fixed Effects, SDP - Spatial Dynamic Panel approach.

where ${ }^{y_{i}}$ is the GDP per capita in the $i$-th region. ${ }^{\delta_{0}}$ is the estimate of the average ${ }^{y_{i}}$ in the group of not supported regions (control group) over the reference period. $t 2$ is a dummy variable equal to 1 for the financial intervention period and equal to 0 for the reference period.

$\delta_{1}$ shows how ${ }^{y_{i}}$ average in the control group changed over the financial intervention period, compared with the reference period, i.e. how regional GDP per capita has changed without regional support. ${ }^{s_{i}}$ is a dummy variable equal to 1 if the region received support and equal to 
0 otherwise. ${ }^{\delta_{2}}$ shows how ${ }^{y_{i}}$ average differed between regional support recipients and control group already before the financial intervention took place, i.e. it shows the initial (over the reference period) difference between the supported and not supported regions in terms of GDP per capita. We expect to estimate a negative parameter on ${ }^{\delta_{2}}$ since CP focuses on less developed regions. $\delta_{D I D}$ is the DID parameter which shows the effect of support, i.e. whether the initial negative differences between the support recipients and the control group became

smaller due to regional support. A positive parameter on $\delta_{D I D}$ would give evidence that the initial differences observed over the reference period became smaller over the financial intervention period, i.e. regional support contributed to regional convergence. $e_{i}$ is the error term.

We assume that regions will not respond to SF transfers in the same way simply because the intensity of support is not the same across regions. To put in other words, the effect of regional support hinges on the intensity of regional support. Thus, we expect some heterogeneity in the impact across regions as well. We can estimate the DID assuming heterogeneity of the support effect by interacting ${ }^{s_{i}}$ dummy with the regional support intensity, ${ }^{S_{i}}$. If a region does not receive financial support, ${ }^{s_{i}}$ and $S_{i}$ as well as their interaction are equal to zero. If a region receives support, $s_{i}$ is equal to unity and its interaction with $S_{i}$ is equal to $s_{i}$. Thus, $s_{i}$ substituting with ${ }^{S_{i}}$ we will estimate the effect of regional support intensity on the dynamics of the disparities:

$$
y_{i}=\delta_{0}+\delta_{1}-t 2+\delta_{2}-S_{i}+\delta_{D I D} \cdot t 2 \cdot S_{i}+\varepsilon_{i}
$$

where $\delta_{D I D}$ now measures the effect of regional support intensity change by one unit on regional GDP per capita. $\delta_{2}$ is expected to be negative since it shows the correlation between the regional support intensity over the financial intervention period and regional GDP per capita over the reference period.

To relax an assumption that the effect of ${ }^{S_{\mathrm{i}}}$ on the outcome is constant, i.e. that relationship is linear, we introduce the quadratic specification:

$$
y_{i}=\delta_{0}+\delta_{1}-t 2+\delta_{21}-S_{i}+\delta_{22}-S_{i}^{2}+\delta_{D I D 1}-t 2 \cdot S_{i}+\delta_{D I D 2}-t 2 \cdot S_{i}^{2}+\varepsilon_{i x}
$$

Statistically significant and positive $\delta_{D I D 1}$, and statistically significant and negative $\delta_{D I D 2}$ would give evidence of a quadratic form of relationship in the form of an inverted U-shaped letter with a marginal effect of regional support intensity on ${ }^{y_{i}}$ calculated as:

$$
\frac{\partial\left(y_{i}\right)}{\partial\left(S_{i}\right)}=\delta_{D I D 1}+2-\delta_{D I D 2}-S_{i}
$$

In the case of interactive Eqs. (1) and (2), after the first differencing or time-demeaned transformations, they collapse to simple additive models for the second (financial intervention) period and estimated standard errors on coefficients associated with DID parameter are 
general ones. These two alternative transformations are used to control all region-specific timeconstant effects. For example, the geographical position of the region, which determines its access to infrastructure, such as seaports, highways, etc., or the economic linkages between regions, which can be an essential growth factor for the peripheral regions situated near core regions. The same transformations also help to control the effects that are subject to slow change over a relatively short time period, for example, the demographic or economic structure of the region. Having little possibility to control these effects by including all necessary variables at NUTS3 level, an unexplained variation which now would account for a part of the error term

could lead to a correlation between $\bar{\varepsilon}_{\mathrm{i}}$ and $y_{i}$ as well as between $\bar{\varepsilon}_{\mathrm{i}}$ and $S_{\mathrm{i}}$. This correlation is very likely to occur since regional support is not randomly distributed among regions, but it depends on the regional characteristics, which are also related to its growth and thus impose an endogeneity problem.

However, in the case of the Eq. (3) the multiplicative term is retained after the first differencing or time-demeaned transformations for the second period $(t 2=1)$ :

$$
\begin{aligned}
& \ddot{y}_{i}=\delta_{0}+\delta_{1}-(1)+\delta_{D I D 1}{ }^{-}(1)-\ddot{S}_{i}+\delta_{D I D 2}{ }^{-}(1)-\bar{S}_{i}^{2}+\varepsilon_{i} \\
& \ddot{y}_{i}=\left(\delta_{0}+\delta_{1}\right)+\left(\delta_{D I D 1}+\delta_{D I D 2}-\tilde{s}_{i}\right)-\tilde{s}_{i}+\varepsilon_{i x}
\end{aligned}
$$

where stands for the time-demeaned variable. Using the first-differencing, we would yield quite the same equation, just $\delta_{0}$ would not be retained. Therefore, not just the marginal effect of $S_{i}$ on $y_{i}$, i.e. slope $\left(\delta_{D I D 1}+\delta_{D I D 2}{ }^{-} S_{i}\right)$ is conditioned on the value of $S_{i}$ itself, but following Friedrich (1982), we can argue that the standard error of the slope coefficient is also conditioned on ${ }^{S_{i}}$ value and standard error of the sum $\left(\delta_{D I D 1}+\delta_{D I D 2}-S_{i}\right)$ is:

$$
S E_{\left(\delta_{D I D 2}+\delta_{D I 2}-S_{i}\right)}=\sqrt{\operatorname{var}\left(\delta_{D I D 1}\right)+S_{i}^{2}-\operatorname{var}\left(\delta_{D I D 2}\right)+2-S_{\mathrm{i}}-\operatorname{cov}\left(\delta_{D I D 1}, \delta_{D I D 2}\right)} \text {. }
$$

This implies that the estimated marginal effect of ${ }^{S_{i}}$ on ${ }^{y_{i}}$ can potentially be not significant over the whole range of observed ${ }^{S_{i}}$ values, i.e. it is not necessary to reach the tipping point of $S_{i}$ for the marginal effect not to differ from zero. In line with the usual logic of constructing for a coefficient, a test of statistical significance against the possibility that the population parameter is zero, the $t$ value for the marginal effect of ${ }^{S_{i}}$ on ${ }^{y_{i}}$ can be calculated, when ${ }^{s_{i}^{2}}$ is added to the equation, as:

$$
t=\frac{\delta_{D I D 1}+\delta_{D I D 2}-S_{i}}{S E_{\left(\delta_{D I D 1}+\delta_{D D 2}-S_{1}\right)}}
$$

Having an empirical relationship between ${ }^{y_{i}}$ and $S_{i}$ in the form of an inverted U-shaped letter, Eq. (7) enables us to test what the minimum level of ${ }^{S_{i}}$ is required for the marginal effect of ${ }^{S_{i}}$ on $y_{i}$ to become significant and whether the marginal effect of $S_{i}$ is still 
significant when the turning point is reached and the marginal effect becomes negative.

The data for the empirical estimation at NUTS 3 aggregation level are collected from Eurostat and SWECO (2008). The regional GDP per capita at constant prices is considered as the dependent variable, i.e. ${ }^{y_{i}}$. Since the data on regional support are provided for the whole period rather than on a yearly basis, we calculated the regional support intensity, i.e. ${ }^{S_{i}}$ as the ratio between the dedicated funds for a particular region over the 2000-2006 programming period and the overall regional GDP over the same period. Over the 2000-2006 programming period, all EU-25 MS were under CP's consideration, encompassing 1251 NUTS3 regions in total. 244 regions, which did not receive any support over the $2000-2006$ programming period,

will serve as a control group. Regional support intensity, i.e. ${ }^{S_{i}}$, for 1007 financially supported regions ranges from 0.00015676 per cent up to 13.506 per cent with an average and median values of 0.5043 and 0.1427 , respectively. The correlation between ${ }^{S_{i}}$ and the average $y_{i}$ over the reference period is $-0.4028(n=1007, p$-value<0.0001). Being statistically significant, the negative correlation suggests that the less developed regions were financially supported more intensively.

Since the earliest data at NUTS 3 level is available from 1995, the period of 1995-1999 in our research will be considered as the reference or pre-intervention period. The period's average

$y_{i}$ over 1995-1999 for financially supported regions was lower by 23.8 per cent, compared to regions in the control group. The 2000-2006 period is considered as the financial intervention period. Throughout 2000-2006, compared with the reference period, the difference between the support recipients and regions in the control group increased by 1 p. point. It is not evidence of CP's failure since we do not know how much the differences would have increased in the case that CP would not be presented at all. Estimating the effect of SF transfers on the convergence over 2000-2006 would allow examining the short-run convergence effects of regional support. One post-intervention period considered in our research is 2007-2011, over which the difference increased up to 25.7 per cent. Since the period of 2007-2011 encompasses the Great Financial Crisis, which at some point could distort the estimation results, and since the regions were able to spend the last allocation available until the end of 2009 , what could affect the occurrence of the outcomes just after 2009, we alternatively consider 2010-2014 as the post-intervention period. Extending the period more, i.e. including the year 2015 or 2016, could, at some extent, cover the effects of the allocations of the next, i.e. 2007-2013, programming period. Estimating the effect of SF transfers on convergence over 2007-2011 and 2010-2014 allows examining the long-run convergence effects of regional support.

The DID approach requires that the group of regions granted for SF support and regions in the control group would meet the common trend assumption. That is, if the regional support has not been provided, there would not exist systematic differences in the outcome variable trend of changes between the two groups over time. Since the average growth rate of regional GDP per capita at constant prices over 1995-1999 was 2.36 and 2.62 per cent for control and financially supported groups, respectively, and since we did not fail to reject the null - trends of changes are equal, the difference in growth trends is used for the adjustment, and differentialtrend-adjusted GDP per capita at constant prices is used as the dependent variable. 
Mindaugas BUTKUS, Diana CIBULSKIENĖ, Alma MAČIULYTÉ-ŠNIUKIENĖ, Kristina MATUZEVIČIUTĖ

\section{Results}

The fixed effects estimates of Eq. (3), examining the non-linear relation between the regional support intensity and convergence, are reported in Table 3.

Table 3

Fixed effects estimates

\begin{tabular}{|c|c|c|c|c|}
\hline Variable & Parameter & (1) & (2) & (3) \\
\hline \multirow{2}{*}{ Intercept } & \multirow{2}{*}{$\delta_{0}$} & $9.820^{\star \star \star}$ & $9.819^{\star \star \star}$ & $9.820^{\star * *}$ \\
\hline & & $(0.002)$ & $(0.002)$ & $(0.002)$ \\
\hline \multirow{2}{*}{$t 2$} & \multirow{2}{*}{$\delta_{1}$} & $0.155^{\star \star *}$ & $0.214^{\star * *}$ & $0.222^{\star \star \star}$ \\
\hline & & $(0.004)$ & $(0.005)$ & $(0.005)$ \\
\hline \multirow{2}{*}{$t 2 \cdot S_{i}$} & \multirow{2}{*}{$\delta_{D I D 1}$} & $0.014^{*}$ & $0.042^{\star \star \star}$ & $0.035^{\star \star \star}$ \\
\hline & & $(0.008)$ & $(0.011)$ & $(0.011)$ \\
\hline \multirow{2}{*}{$t 2 \cdot S_{i}^{2}$} & \multirow{2}{*}{$\delta_{D I D 2}$} & -0.001 & $-0.002^{\star \star}$ & $-0.002^{\star *}$ \\
\hline & & $(0.001)$ & $(0.001)$ & $(0.001)$ \\
\hline \multicolumn{2}{|c|}{$\mathrm{N}$} & 2502 & 2502 & 2502 \\
\hline \multicolumn{2}{|c|}{ Within R-squared } & 0.633 & 0.671 & 0.678 \\
\hline
\end{tabular}

Notes: Robust (using HCCME) standard errors are presented in parentheses. ${ }^{*},{ }^{* *}$, ${ }^{* *}$ indicate statistical significance at the $10 \%, 5 \%$, and $1 \%$ levels, respectively. All estimates use logged differentialtrend-adjusted GDP per capita at constant prices as dependent variables. Estimates in column (1) report effects for 2000-2006, column (2) over 2007-2011, column (3) over 2009-2013.

Est. (1) shows that there is no statistically significant unconditional linear or non-linear effect of regional support on convergence over the financial support period since we did not fail to reject the hypotheses that both parameters on DID are equal to zero at a standard significance level. It suggests that either the financial support period is too short for the convergence outcomes of regional support to occur or the significance of the effect differs depending on the intensity of the support. On the contrary, Est. (2) and (3), for both post-intervention periods, show similar DID parameters in terms of their size and significance. The estimated coefficients on the nonsquared term being positive and on the squared term being negative, both statistically significant, suggest that the effect of regional support on reducing regional disparities over the long-run is positive but marginally diminishing. The estimated turning point (using Eq. (4)) occurs when $S_{i}$ reaches around 8.59-9.24 per cent. This turning point covers almost the whole observed range of $S_{i}$, because there are just 2 regions (out of 1007) with the $S_{i}$ level above the estimated tipping point.

Fig. 1 represents the estimated non-linear relation between the convergence and regional support intensity for the financial intervention period (Est. (1)) and both post-intervention periods (Est. (2) for 2007-2011 and Est. (3) for 2009-2013).

Since we do not observe regions with $S_{i}$ values from 6.65 up to 12.75 , Fig. 1 (a) does not picture that relation between convergence and $S_{i}$ is non-linear, i.e. the marginal return on EU's regional support is conditioned on the level of support intensity. Fig. 1 (b) plots the same relationship, but with added not observed values of $S_{i}$. Our estimations provide evidence for that the return on the EU's regional support is positive and higher for the post-intervention period (over long-run), compared with the return over the financial intervention period (over short-run). The curves representing the relation over the post-intervention period are above the curve that represents the relation over the financial intervention period, i.e. at the same level of $S_{i}$, the return is higher over the long-run. Our estimations suggest that support has a way more 
significant effect when the programming period ends and when the support is fully absorbed, i.e. it takes many years for the considerable support effects to appear. Considering a strategic investment in infrastructure, human capital, etc., directed to promote long-run competitiveness, it can take decades for the effect to appear.
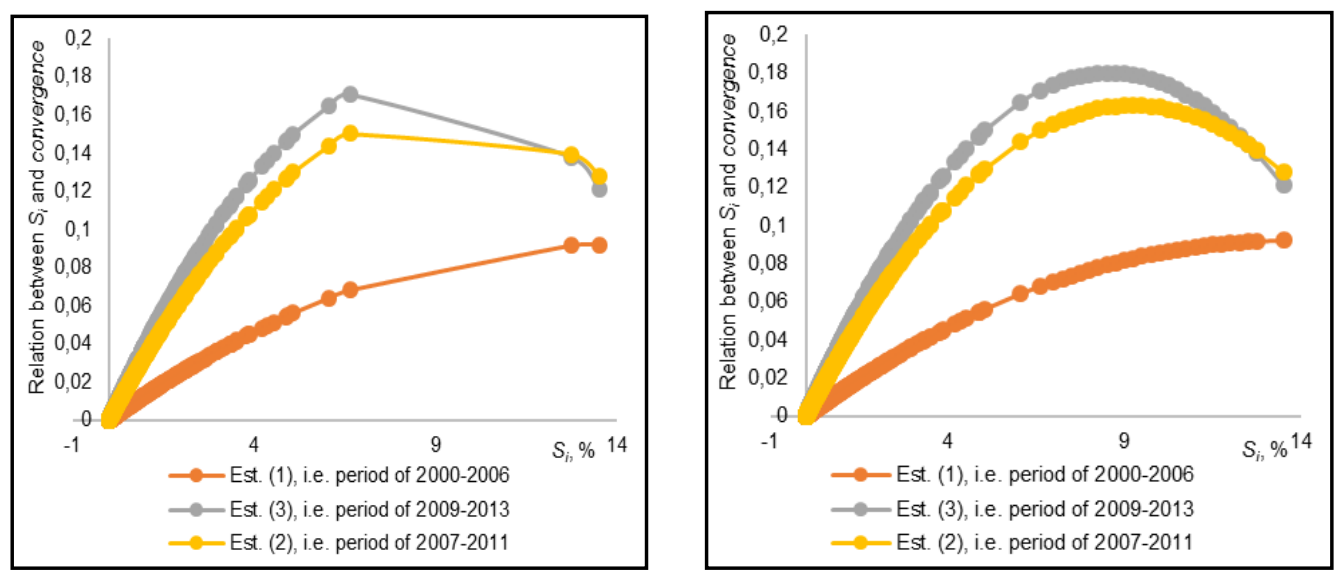

Fig. 1 - The estimated non-linear relation between regional support intensity and convergence

(a) over observed $S_{i}$ values and (b) with additional $S_{i}$ values

We also see that the relation between convergence and $S_{i}$ is much more curved over the postintervention period, compared to the financial intervention period, i.e. a curve being flatter for the financial intervention period shows that the marginal return is of less dependency on the regional support intensity, compared to the post-intervention period. Probably, it is more important to consider the non-linear relation modelling the return on EU's regional support over the long-run, while over short-run the non-linear effects do not manifest.

Having an empirical relationship between $S_{i}$ and convergence in the form of an inverted $U$ shaped letter, Eq. (7) enables us to test what the minimum level of $S_{i}$ is required for the marginal effect of $S_{i}$ on convergence to become significant and whether the marginal effect of $S_{i}$ is still significant when the turning point is reached and the marginal effect becomes negative. To illustrate this with our example, we took the earlier discussed estimations from Table 3. Table 4 reports the variance and covariance of estimated DID parameters.

Table 4

Variance - covariance of DID parameters

\begin{tabular}{|c|c|c|c|}
\hline Variance-covariance & \multicolumn{3}{|c|}{ Estimates } \\
\cline { 2 - 4 } & $\mathbf{( 1 )}$ & $\mathbf{( 2 )}$ & $\mathbf{( 3 )}$ \\
\hline $\operatorname{var}\left(\delta_{\text {DID1 }}\right)$ & $6.06 \mathrm{E}-05$ & $1.13 \mathrm{E}-04$ & $1.11 \mathrm{E}-04$ \\
\hline $\operatorname{var}\left(\delta_{\text {DID2 }}\right)$ & $3.47 \mathrm{E}-07$ & $9.17 \mathrm{E}-07$ & $8.52 \mathrm{E}-07$ \\
\hline $\operatorname{cov}\left(\delta_{D I D 1}, \delta_{D I D 2}\right)$ & $-4.42 \mathrm{E}-06$ & $-9.19 \mathrm{E}-06$ & $-8.94 \mathrm{E}-06$ \\
\hline
\end{tabular}


Using Eq. (6) and (7), we calculated the standard errors (Fig. 2) and t-ratios (Fig. 3) of slopes conditioned on $S_{i}$ values. Part (a) reports the observed range of $S_{i}$ and part (b) includes the additional unobserved $S_{i}$ values
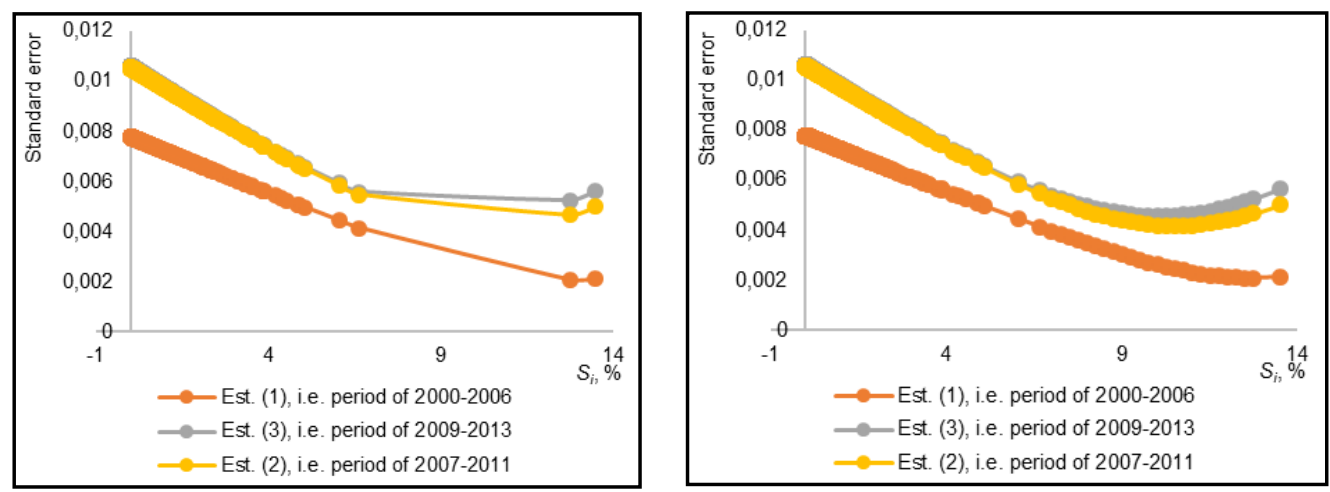

Fig. 2 - The relation between the regional support intensity and the standard error of the slope

(a) over observed $S_{i}$ values and (b) with additional $S_{i}$ values
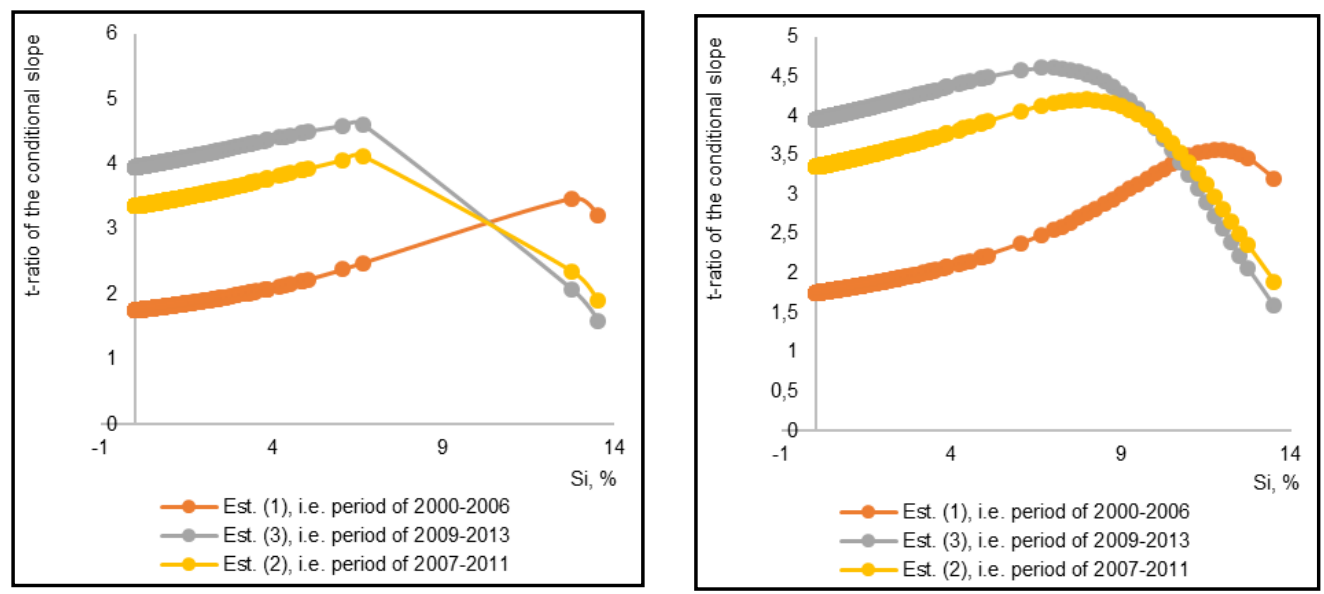

Fig. 3 - The relation between the regional support intensity and the t-ratio of the slope (a) over observed $S_{i}$ values and (b) with additional $S_{i}$ values

Fig. 2 and 3 clearly show that the standard error, as well as t-ratio, associated with the slope coefficient, are not constant and as marginal effect of $S_{i}$ on convergence depends on the values of $S_{i}$. Having in mind that with $95 \%$ confidence level and with the degree of freedom above 1000, the critical value for the t distribution is 1.960, in Fig. 4 we presented the marginal effect of $S_{i}$ on convergence over the range of $S_{i}$ values for which this effect is statistically significant.

The estimations for the post-intervention period yield the marginal effects that are significant for all $S_{i}$ values, except for the right-side extreme. This provides evidence that (i) there is no need for a minimum amount of regional support for the effect to become significant, i.e. even low 
intensity of the EU's regional support significantly reduces regional differences, i.e. it promotes convergence over the long-run, and (ii) the marginal effect of $S_{i}$ after the turning point remains statistically significant although it is negative what suggests the overfunding and the faster overall convergence by redistributing the support to less intensively supported regions. Estimations for the financial intervention period provide evidence that the marginal effect is not significant for low values of $S_{i}$ and it become significant when the intensity is above $2.5 \%$. This could be because the low level of regional support intensity is not increasing the expenditures in the region enough to ensure the sufficient jump of regional GDP per capita over the financial intervention period for the regional disparities significantly to decrease.

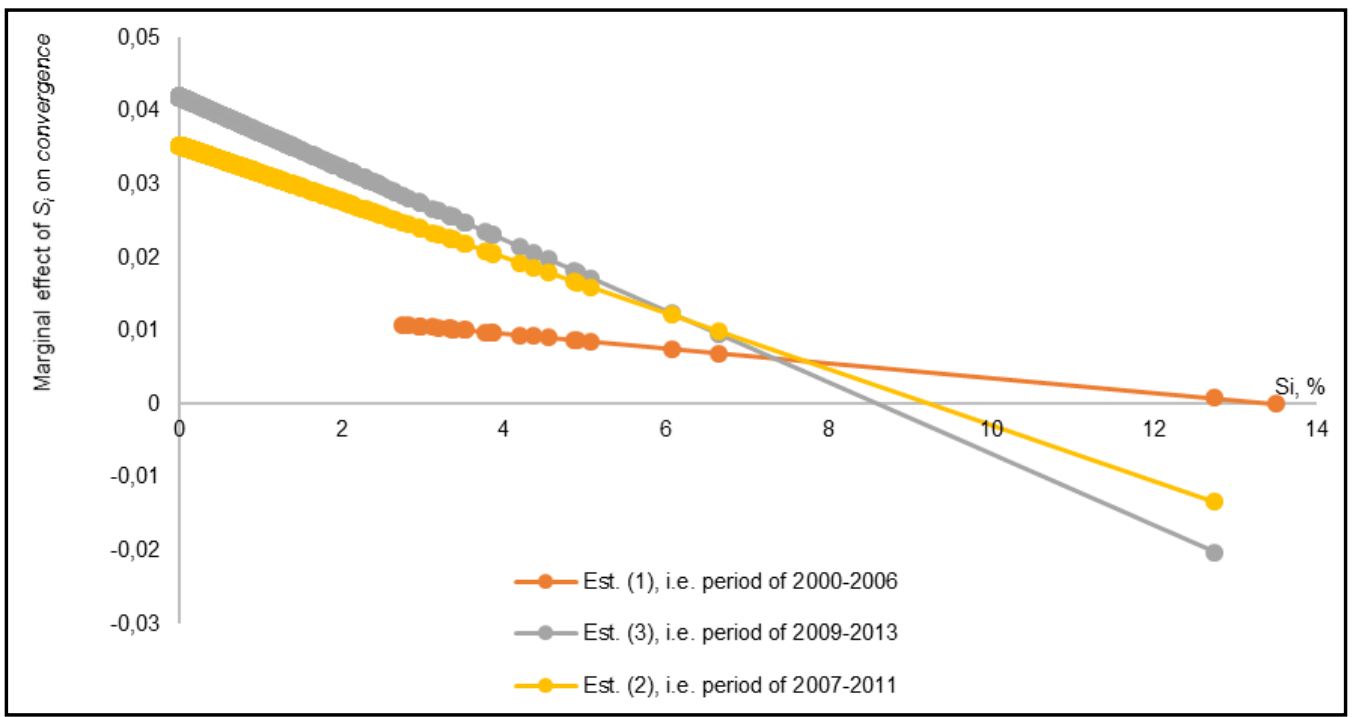

Fig. 4 - The statistically significant marginal effect of regional support intensity on the convergence over the observed range of $S_{i}$ values

Summing up, we have found a stronger statistical evidence within the framework of our proposed model that over the post-intervention support period the relation between regional support intensity and convergence is non-linear, i.e. that the marginal effect of regional support intensity is conditional and it depends on the level of the intensity. We also showed that in the case of non-linear modelling, it is crucial to consider that not only slope but also the standard error associated with the slope coefficient is conditional too. This implies that the marginal effect of $S_{i}$ on the outcome is not necessarily significant over all the values of regional support intensity, even though this effect is positive or negative.

\section{Discussion}

Our results considering the non-linear relation between regional support intensity and convergence are not directly comparable with the existing empirical evidence since we estimate the effect on convergence rather than on growth or unemployment, i.e. two primary outcomes mostly used in literature, and since we work with a smaller - NUTS3 disaggregation level, while the previous studies focus at country and/or at NUTS1/2 level. Nevertheless, we can draw some similarities with the small number of contributions dealing with the non-linear effects of support. As in the majority of previous contributions, we find that SF and CF support generates positive outcomes. We also find that EU's regional support via 
SF and CF has no constant effect and it depends on the amount of treatment. Our findings also support the view that the intensity of EU's funding is a subject to diminishing marginal returns, i.e. the bigger "dose" of the funding does not guarantee a higher level of the desirable outcome. Although our estimated turning points are way beyond the ones estimated by the previous research, our results suggest the need for SF and CF redistribution in favour of less intensively financed regions to speed up convergence. This conclusion is supported by the findings of Pieńkowski and Berkowitz (2016) and Becker (2012) who also argued that CP transfers should have been relocated from the regions receiving the highest transfer intensity to the regions receiving fewer funds and leading to a higher convergence among the regions.

Nevertheless, there is an undergoing debate that CP should continue investing in all regions, including the richer MS as well. CP is still keeping, in the new funding period, three categories of regions: less-developed, transition and more developed (more prosperous) regions (European Court of Auditors 2019), raising the question whether it will help to reallocate EU's funding in favour of low-income and low-growth regions to catch up. As Dellmuth and Chalmers (2018) underlined, there could be not enough spill-over e $\square$ ects on the rest of the EU from public investment in more prosperous regions, suggesting that the funding of the rich should come from either local or national, rather than EU, resources. Further, following Marzinotto (2012), who argued that SF and CF should be used to smoothen the regional level funding reallocation, we can add that it is crucial to create conditions for NUTS 3 regions within NUTS 2 regions to exploit their comparative advantage.

Considering our research results, some limitations of the study and directions for further research could be highlighted. Comparing long- and short-run effects, they show a similar pattern with the existing literature. Nevertheless, contrary to Mohl and Hagen $(2008,2010)$, and CSIL and DKM Economic Consultants (2012), we find an instant (over financial intervention period) positive marginal effect of support on convergence when the intensity of regional support is above $2.3 \%$. It might suggest that we probably observe some dummy effects of EU's regional support, at least over the ongoing programming period, which should prevent us from the too early evaluation of support success. One possible explanation of that could be the fact that regional support, as additional expenditures in the region's economy, directly increases regional GDP per capita over the financial intervention period. Since $S_{i}$ negatively correlates with GDP per capita, more regional support directed to the least developed regions leads to the bigger jump of regional GDP per capita over the financial intervention period. All that directly leads to smaller differences between regions over the same period, i.e. higher $S_{i}$ corresponds to the higher jump of GDP per capita and lower disparities. However, over the long run, due to the reasons discussed in the literature review, regions which are more intensively supported and do not have the shortage of funds could potentially direct support to the unproductive areas what could turn into adverse outcomes, slower growth, and GDP per capita way below its potential level. It seems that facing the scarcity of regional support, regions are encouraged to use them more efficiently and to reach higher returns with less financial inputs.

Moreover, the success of one programming period becomes hard to distinguish from the investments made over the next programming period due to the overlapping effects. Even more, the results suggest that a more significant effect of regional support on the diminishing regional disparities occurs over a long period, but the potentially positive effect could be hard to isolate from other factors.

\section{Conclusions}

Despite the extensive literature on the impact of the $\mathrm{CP}$ on regional economic growth in general, there is little evidence of its impact on convergence, which is the primary goal of the $\mathrm{CP}$. There is also limited evidence testing other than a linear form of relationship between the intensity of SF and CF payments and the policy outcomes. Even if, in theory, more EU 
transfers might generate a faster growth, in reality, it appears that there may well be decreasing marginal returns from the investment and investment-stimulating transfers. Therefore, the regional support should not exceed the maximum desired level of intensity, which might influence the return on support and also the overall policy effectiveness and regional growth in general, to avoid inefficiency and misuse.

Summarising the previous contributions, we can conclude that the moral hazard and substitution effects might cause a non-linear relationship between SF and CF commitments and economic growth or convergence. These effects can be related to the level of institutional quality that may cause the inefficient use of EU regional support if funds are spent on unproductive projects. The previous studies reveal the diminishing marginal growth returns of SF. Thus, it is crucial to understand how the varying treatment intensity (different amounts of EU transfers relative to GDP) affects regional convergence. The main limitations of previous research are as follows: (I) they do not assess the non-linear relationship between the intensity of SF and CF transfers and convergence to determine the desirable level of intensity; (ii) mainly short term effects are considered, however, CP transfers may have a long-run effect as well; and (iii) the main focus is at NUTS2 disaggregation level.

Filling this gap, we examined whether the intensity of SF and CF transfers has non-linear effects on convergence at NUTS3 regional level over short- and long-run. Modifying the standard DID specification to account for non-linear and heterogeneous effects of CP policy, we estimated the equation using fixed effects and we considered non-constant the standard errors and t-ratios of the estimated marginal effect of treatment intensity on convergence.

We have found evidence that the return is positive and higher for the post-intervention period, compared with the return over the financial intervention period, i.e. higher positive effect to diminish disparities is expected over long-run. Estimates of marginal effects for the postintervention period are significant over all values of regional support intensity except for high extreme. On the contrary, estimations for regional support period provide evidence that the marginal effects are not significant for low values of SF payment intensity, thus giving an insight that not all less intense SF transfers, at least over short-run, significantly diminish disparities. All in all, the study confirms the initial assumption that the EU's regional support is subject to diminishing marginal effects and it points out that high levels of support intensity are highly unjustifiable in terms of CP's efficiency.

\section{Acknowledgements}

This work is a part of the Researchers' group project on The Assessment Model of Return on the EU Regional Support (AMREUS) that has received funding from the Research Council of Lithuania under agreement No. S-MIP-17-114.

\section{References}

BONDONIO D., PELLEGRINI G. (2016), Macro-economic effects of cohesion policy funding in 2007-2013. Executive Summary, European Commission, Publications Office of the European Union, Luxembourg.

BARCA F. (2009), An Agenda for a Reformed Cohesion Policy: A Place-based Approach to Meeting European Union Challenges and Expectations, Retrieved from: www.europarl.europa.eu.

BECKER S. O., EGGER P. H., VON EHRLICH M. (2010), Going NUTS: The effect of EU structural funds on regional performance, Journal of Public Economics 94 (9-10), 578-590. BECKER S. O., EGGER P., VON EHRLICH M. (2012), Too Much of a Good Thing? On the Growth Effects of the EU's Regional Policy, European Economic Review 56 (4), 648-668. BECKER S. O., EGGER P. H., VON EHRLICH M. (2013), Absorptive Capacity and the 
Growth and Investment Effects of Regional Transfers: A Regression Discontinuity Design with Heterogeneous Treatment Effects, American Economic Journal: Economic Policy 5 (4), 29-77. BECKER S. O., EGGER P. H., VON EHRLICH M. (2018), Effects of EU Regional Policy: 1989-2013, Regional Science and Urban Economics 69, 143-152.

BEUGELSDIJK M. S, EIJFFINGER S. C. W. (2005), The effectiveness of structural policy in the European Union: An empirical analysis for the EU-15 in 1995-2001, Journal of Common Market Studies 43 (1), 37-51.

CAPPELEN A., CASTELLACCI F., FAGERBERG J., VERSPAGEN B. (2003), The Impact of EU Regional Support on Growth and Convergence in the European Union, Journal of Common Market Studies 41 (4), 621-644.

CENTRE FOR INDUSTRIAL STUDIES (CSIL), DKM ECONOMIC CONSULTANTS

(2012), Ex post evaluation of investment projects co-financed by the European Regional Development Fund (ERDF) or Cohesion Fund (CF) in the period 1994-1999: Ten projects observed, Retrieved from: www.op.europa.eu.

CERQUA A., PELLEGRINI G. (2018), Are we spending too much to grow? The case of Structural Funds, Journal of Regional Science 58 (3), 535-563.

DEL BO C., FLORIO M., SIRTORI E., VIGNETTI S. (2011), Additionality and regional development: are EU Structural Funds complements or substitutes of national public finance?, Centre for Industrial Studies (CSIL), Retrieved from: www.csilmilano.com.

DELLMUTH L. M., CHALMERS A. W. (2018), All spending is not equal: European Union public spending, policy feedback and citizens' support for the EU, European Journal of Political Research 57 (1), 3-23.

DI CATALDO M., MONASTIRIOTIS V. (2020), Regional needs, regional targeting and regional growth: an assessment of EU Cohesion Policy in UK regions, Regional Studies 54 (1), 35-47.

EDERVEEN S., GORTER J., DE MOOIJ R., NAHUIS R. (2003), Funds and Games: The Economics of European Cohesion Policy, European Network of Economic Policy Research Institutes, Brussels.

EUROPEAN COMMISSION (2016), Measuring the impact of Structural and Cohesion Funds using the Regression Discontinuity Design: Ex post evaluation of Cohesion Policy programmes 2007-2013, focusing on the European Regional Development Fund (ERDF) and the Cohesion Fund (CF), Publications Office of the European Union, Luxembourg.

EUROPEAN COURT OF AUDITORS (2019), Allocation of Cohesion policy funding to Member States for 2021-2027, Retrieved from: www.eca.europa.eu.

FRIEDRICH R. J. (1982), In defense of multiplicative terms in multiple regression equations, American Journal of Political Science 26 (4), 797-833.

GORZELAK G. (2016), Cohesion Policy and regional development, in: Bachtler J., Berkowitz P., Hardy S., Muravska T. (eds.), EU Cohesion Policy: Reassessing performance and direction, Routledge, London and New York, pp. 33-54.

HAGEN T., MOHL P. (2008), Which is the Right Dose of EU Cohesion Policy for Economic Growth?, ZEW Discussion Paper No. 08-104, Retrieved from: www.zew.de.

KYRIACOU A. P., ROCA-SAGALÉS O. (2012), The Impact of EU Structural Funds on Regional Disparities within Member States, Environment and Planning C: Politics and Space 30 (2), 267-281.

MARZINOTTO B. (2012), The growth effects of EU cohesion policy: a meta-analysis, Bruegel Working Paper No. 2012/14, Retrieved from: www.bruegel.org.

MOHL P., HAGEN T. (2008), Does EU Cohesion Policy Promote Growth? Evidence from Regional Data and Alternative Econometric Approaches, ZEW Discussion Paper No. 08086, Retrieved from: www.zew.de

MOHL P., HAGEN T. (2010), Do EU Structural Funds Promote Regional Employment? Evidence from Dynamic Panel Data Models, European Central Bank Working Paper Series No. 1403, Frankfurt am Main.

PIEŃKOWSKI J., BERKOWITZ P. (2016), Econometric assessments of Cohesion 
Policy growth effects: How to make them more relevant for policymakers?, in: Bachtler J., Berkowitz P., Hardy S., Muravska T. (eds.), EU Cohesion Policy: Reassessing performance and direction, Routledge, London and New York, pp. 55-68.

PIETAK Ł. (2018), Did structural funds affect economic growth and convergence across regions? Spanish case in the years 1989-2016, INE PAN Working Paper Series 44, Retrieved from: www.inepan.pl.

PINHO C., VARUM C., ANTUNES M. (2015), Structural Funds and European Regional Growth: Comparison of Effects among Different Programming Periods, European Planning Studies 23 (7), 1302-1326.

PONTAROLLO N. (2016), Does Cohesion Policy affect regional growth? New evidence from a semi-parametric approach, in: Bachtler J., Berkowitz P., Hardy S., Muravska T. (eds.), EU Cohesion Policy: Reassessing performance and direction, Routledge, London and New York, pp. 69-83.

RODRÍGUEZ-POSE A., FRATESI U. (2002), Unbalanced development strategies and the lack of regional convergence in the EU, ERSA 2002 - 42nd Congress of the European Regional Science Association, 1-60.

RODRÍGUEZ-POSE A., NOVAK K. (2013), Learning processes and economic returns in European Cohesion policy, Investigaciones Regionales 25, 7-26.

SWECO (2008), Final Report - ERDF and CF Regional Expenditure, Retrieved from: www.ec.europa.eu.

SZITÁSIOVÁ V., MARTIŠKOVÁ M., ŠIPIKAL M. (2014), Substitution Effect of Public Support Programs at Local Level, Transylvanian Review of Administrative Sciences 10 (SI), 167-182.

WALLACE H., POLLACK M. A., YOUNG A. R. (2015), Policy-making in the European Union, Oxford University Press, Oxford.

WOSTNER P., SLANDER S. (2009), The effectiveness of EU cohesion policy revisited: are EU funds really additional?, European Policies Research Centre, Glasgow.

Initial submission: 17.07.2019

Revised submission: 15.02 .2020

Final acceptance: 17.02 .2020

Correspondence: Institute of Regional Development, Siauliai University, Vilniaus g. 88, 76285 Šiauliai, Lithuania.

Email: matuzeviciute@gmail.com 
